http://dx.doi.org/10.12775/szhf.2013.020

Jolanta ŻELAZNA

\title{
Zrozumieć wyobraźnię
}

Koniec zimy, właściwie przedwiośnie; środek tygodnia, popołudniowy szczyt komunikacyjny, okropna pogoda - przenikliwy wiatr zacinający deszczem, ciemno i ponuro. Przepełniony autobus: młodzież objuczona ciężkimi plecakami, dorośli z zakupami i z dziećmi, wszyscy zmierzają na obrzeża miasta do dzielnic-sypialni. Kierowca szarpie za sprzęgło, pasażerowie raz po raz zderzają się z sobą i swoimi bagażami. W pewnym momencie słyszę, jak za moimi plecami rozdrażniony kobiecy głos przywołuje kogoś do porządku:

- No co pan wyprawia! Trzymać się trzeba! Co pan sobie wyobraża!

Natychmiast po tej tyradzie, wykrzyczanej, jak mi się wydawało, przez damę w średnim wieku, padła riposta:

- Że pani tu nie ma.

Pomińmy wszystko, co zdarzyło się zaraz potem; każdy, kto korzysta z usług miejskiego przewoźnika, wie, jak zwykły rozwijać się tego rodzaju incydenty. Nie zamierzam również komentować zachowania młodego człowieka, który zapewne bez złej woli, tylko wskutek tłoku, wadliwego działania sprzęgła i właściwej rzeczom bezwładności najwyraźniej nie pierwszy raz podczas tej podróży uderzył plecakiem stojącą za nim pasażerkę. Jego odzywka, bez względu na jej stosowność, a raczej jej brak, zawiera jednak zastanawiający sąd o możliwościach ludzkiej wyobraźni.

„Ty to masz wyobraźnię!” - podobna opinia wypowiedziana z podziwem może napełnić adresata dumą; jeśli jednak w głosie mówiącego słychać sarkazm, właściciel bujnej wyobraźni powinien się poczuć skarcony. Mimo wszystko wydaje się, że lepiej być uznanym za fantastę niż narazić się na za- 
rzut bycia człowiekiem bez wyobraźni. Ta ostatnia fraza brzmi wprost złowieszczo.

Dwuznaczność powyższej opinii wynika z pewnego niuansu - treść i ton podobnych wypowiedzi mogą się zgadzać bądź przeczyć sobie, sprawiając, że nie wiemy na pewno, kto (lub co) jest posiadaczem pewnej własności. Posiadanie wyobraźni, czyli władanie nią, to stan z gruntu przeciwny wobec tego, w którym wyobraźnia posiada człowieka, sterując nim wedle własnych kaprysów.

O obydwu tych sposobach odnoszenia się do wyobraźni, a właściwie fantazji ${ }^{1}$, pisali już filozofowie greccy, uznając ją albo za podstawę wyższych czynności psychicznych, albo za dysfunkcję umysłu, destrukcyjnie wpływającą nie tylko na przebieg poznania, ale również na ludzkie wybory moralne. Pierwszy pogląd charakteryzuje myśl Arystotelesa, drugi znajdziemy w pismach stoików, ze szczególnym upodobaniem atakujących wyobrażenia i wyobraźnię jako stale odradzające się źródło moralnych wad człowieka. Epiktet twierdził: „jeżeli mnie spytasz, co jest dla człowieka prawdziwym dobrem, nie mogę ci dać odpowiedzi innej niż ta, że jest nim czynienie właściwego użytku z wyobrażeń"'. Taki też jest według niego właściwy przedmiot i zadanie filozofii: „wyobrażenia poddać krytycznej ocenie i rozgraniczyć je ściśle, ani jednego $\mathrm{z}$ nich nie przyjmować za dobrą monetę, nie przesiawszy go wpierw przez rzeszoto krytyki"”.

Arystotelesowskie, a po części również stoickie ujęcie kwestii fantazji na długo okazało się wystarczające, tym bardziej, że uwagę myślicieli w następnych epokach skupiły na sobie przede wszystkim problemy dotyczące wza-

\footnotetext{
${ }^{1}$ Potocznie rzadko odróżnia się obydwa te pojęcia. W terminologii filozoficznej pierwszeń-

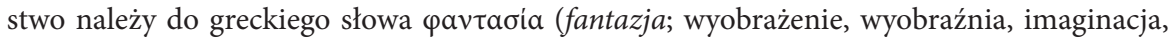
fantazjowanie, wymysł, a nawet urojenie), szerszego znaczeniowo od łacińskiego imaginatio (imaginacja, wyobraźnia, zdolność obrazowania, obrazowego przedstawiania sobie czegoś). Zmyślanie, fantazjowanie, vis creativa zaczyna się od imaginowania (przedstawiania sobie obrazu), lecz idzie dalej w stronę swobodnego komponowania przedstawień i fabularyzowania. Odróżnienie obydwu tych pojęć stało się niezbędne wraz z odejściem od mimetyzmu w sztuce.

${ }^{2}$ Epiktet, Diatryby. Encheiridion, tłum. L. Joachimowicz, Warszawa 1961, Diatryby I, 8, s. 32.

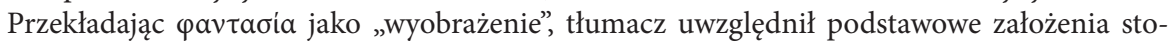
ickiej teorii poznania, w której odróżnia się spostrzeżenia kataleptyczne i akataleptyczne, te drugie uznając już za fikcje (lub jak powiedzielibyśmy dziś - fantazje), generujące w umyśle szkodliwe afekty.

${ }^{3}$ Tamże, I, 20, s. 69.
} 
jemnych relacji wiary i wiedzy oraz możliwości uzgadniania z sobą tych tak źródłowo różnych przejawów ludzkiego życia duchowego.

Naturą i możliwościami wyobraźni ponownie zainteresowano się stosunkowo niedawno, w Oświeceniu, które widziało w niej pośredniczkę łagodzącą sprzeczności istniejące między konkretyzmem poznania zmysłowego i ogólnością pojęć intelektu. Ówczesna potrzeba zwrócenia się w przeszłość i rekonstruowania powszechnej historii ludzkości nie mogła się obyć bez udziału zmysłowego poznania artefaktów ani bez rozumowego usystematyzowania konkretnych danych postrzeżeniowych. Jednakże sam tylko opis fizycznych cech przedmiotów pochodzących z odległych epok nie wystarczał do tego, by można było odgadnąć ich przeznaczenie, cel, dla jakiego zostały sporządzone i wreszcie - na tej podstawie - by pojąć, jak żyli ich użytkownicy. Przy interpretowaniu faktów dziejowych, dostępnych historykom jedynie wyrywkowo, pośrednictwo wyobraźni, tej nie do końca zrozumiałej zdolności ludzkiego umysłu, wymagającej dla siebie spostrzeżeń uprzednio zmagazynowanych w pamięci, władzy post-zmysłowej, ale i pre-racjonalnej, chociaż nader łatwo poddającej się przewodniej sile ratio, okazało się bezwzględnie potrzebne. Doceniono wówczas jej kreatywność, a żywą imaginację uczyniono wartością użyteczną nie tylko dla poznania, lecz również - a niebawem przede wszystkim - dla sztuki. Siła wyobraźni obok mistrzowskiego opanowania techniki stała się swoistym wyróżnikiem artysty, jeszcze do niedawna uznawanego za biegłego rzemieślnika, umiejętnie komponującego dzieła z pieczołowicie przechowywanych przez wieki, gotowych, tradycyjnie dostępnych i powszechnie zrozumiałych figur i symboli ${ }^{4}$.

W tym samym czasie, kiedy wiedza o naturalnych zjawiskach, a więc i o porządku, w jakim ukazują się naszym zmysłom, powiększyła się znacząco, usuwając z umysłów przesądy, zabobony i lęki wywoływane dotąd niezrozumiałym układem mieszających się treści postrzeżeniowych, w swobodzie łączenia pozornie odległych wyobrażeń, właściwej niektórym tylko umysłom zaczęto (i nauczono się) dostrzegać wrodzony, nienabywalny dar, charakterystyczny dla geniusza. Po to jednak, by imaginację oswoić i uznać za siedzibę geniuszu, trzeba było wpierw zdobyć zaufanie do poznawczych mocy samego tylko, czystego ludzkiego rozumu. Wypada również zauważyć, że w tym samym mniej więcej czasie na określenie wyobraźni używano zarówno nazwy imaginacja (kładąc nacisk na ludzką zdolność łączenia postrzeżonych i zapamiętanych obrazów), jak i fantazja (podkreślając siłę, z jaką wyobraźnia

${ }^{4}$ Zob. np. C. Ripa, Ikonologia, tłum. I. Kania, Kraków 2008. 
zdolna jest rozrywać obserwowane stale związki cech, jakości, wielkości i podobnych własności rzeczy, żeby następnie samorzutnie łączyć je w niespotykane w naturze konfiguracje czasoprzestrzenne).

Pojęcie fantazji, greckiego pierwowzoru imaginacji, wróciło do obiegu wraz z renesansowym zainteresowaniem utopią (zarówno jako modelem politycznym, jak i gatunkiem literackim), a następnie utrwaliło się w sztukach plastycznych, gdzie fantazja stała się niezbędnym uposażeniem artysty, skrępowanego koniecznością stosowania się do ścisłych reguł optyki i geometrii, bez których nie sposób było myśleć o rzeźbie, grafice czy malarstwie. Niezwykle konsekwentne badania światła i jego braku, ciemności, prowadzone przez malarzy i uczonych renesansu i baroku, pozwoliły dowiedzieć się więcej o działaniu wzroku i czynnościach intelektu mających za przedmiot to, co widzialne. Eksperymenty dotyczące promieniowania i pochłaniania światła, odbicia i rozpraszania jego promieni, oświetlenia bądź zasłonięcia przedmiotu, wreszcie sąsiedztwa i wzajemnego wpływu barw, ujawniły cały szereg nieznanych wcześniej złudzeń wzrokowych, wpływających na nasz sposób rozumienia obrazów, powstających na siatkówce oka. Poznając jego budowę i uwzględniając działanie soczewki odwracającej obraz, w końcu zrozumiano, jak wiele $\mathrm{w}$ naszym widzeniu świata zależy od władzy, zdolnej z niepojętej gry świateł i mroku tworzyć we wnętrzu ciała dobrze nam znany obraz przestrzeni wypełnionej przedmiotami. Ówczesne malarstwo, rozkwitające dzięki przyswajaniu odkryć między innymi z zakresu optyki i chemii, można by też nazwać fantastyką stosowaną, sposobem spożytkowania wiedzy o naturze i działaniu fantazji, 'ciemnej, ukrytej w zakamarkach ciała mocy chwytania światła i układania z niego nieistniejącego nigdzie poza umysłem ludzkim, spójnego i jasnego obrazu widzialnego świata. Dodajmy - obrazu, zmieniającego się stosownie do okoliczności zewnętrznych wobec oka i calkowicie zależnego od stanu ciała, w którym on powstaje. Jeśli jego struktura może w ogóle przedstawiać coś znajomego, czemu potrafimy nadać nazwę i uznać, że to zwykła rzecz, to jedynie ze względu na pracę ratio, porządkującej ją według systemu kategorii. Powstałe spostrzeżenie ma charakter wizji, fantazyjnie (a nie wiernie) oddającej stan swego źródła. Przekonanie, że jego pozamentalny pierwowzór także cechuje regularność, ma chyba charakter marzenia, któremu zdecydowaliśmy się podporządkować treść spostrzeżeń zmysłowych i o którego trwałość jesteśmy gotowi toczyć najkrwawsze wojny.

O wyobraźni (imaginacji, fantazji) myślimy dziś przede wszystkim w kontekście sztuki i psychologii, uważając ją za typowo ludzką zdolność niemalże nieograniczonego tworzenia kombinacji treści mentalnych, niekoniecznie 
ograniczonych do spostrzeżeń wzrokowych. Mówimy o wyobraźni przestrzennej, dźwiękowej, muzycznej, plastycznej, sytuacyjnej, matematycznej, technicznej, ograniczonej, bujnej, dziecięcej, a nawet chorej; znajdujemy dla niej miejsce niemalże we wszystkich dziedzinach ludzkiej twórczości. Niemalże, gdyż wydaje się wątpliwe, czy pojęcie to kojarzymy z obszarem filozofii praktycznej, tak jak było ono rozpatrywane w epoce Arystotelesa i nieco później, za czasów Zenona z Kition i Epikteta.

Co wiemy o wyobraźni? Zastanówmy się, czy to możliwe, żeby wspomniany na wstępie pasażer o ciętym języku rzeczywiście władał tak zdyscyplinowaną imaginacją, że zapytany o to, co sobie wyobraża - tu i teraz, w zatłoczonym miejskim autobusie - mógł zgodnie z prawdą odpowiedzieć - że pani tu nie ma? Czy można wyobrazić sobie brak, nieobecność czegokolwiek? Co zdolna jest wykreować wyobraźnia, a czego z zasady stworzyć nie potrafi? Czy ma ona jakiś związek z moralnością, z normami, wyznaczającymi granice dozwolonego etycznie zachowania się ludzi? Czy można stworzyć i zalecać stosowanie zasad etyki, wypracowanej jako stanowisko z gruntu negujące sensowność wyobrażania sobie siebie w czyimś położeniu i/lub wyobrażania sobie X-a na swoim miejscu?

Teorie antyczne, zwłaszcza Arystotelesowska i stoicka, znajdują źródło fantazji w ciele, $\mathrm{w}$ jego budowie i związku $\mathrm{z}$ najbliższym otoczeniem, a nie w umyśle. Arystoteles sądził, że umożliwia ona istnienie pamięci, a co za tym idzie, myślenie ${ }^{5}$ i przypisywał fantazję wszystkim zwierzętom jako organizmom wyposażonym w zmysły:

wyobrażenie zdaje się być pewnym rodzajem ruchu i nie może powstać niezależnie od postrzeżenia; [powstaje] jedynie w jestestwach, które postrzegają i w odniesieniu do rzeczy, które są przedmiotami właściwych zmysłów. Ruch [rzeczony] może powstać pod wpływem działania zmysłu; i taki ruch jest z konieczności podobny do postrzeżenia. Konsekwentnie tego rodzaju ruch ani nie jest możliwy bez postrzeżenia, ani nie może mieć miejsca w jestestwach, którym brak postrzeżeń; przeciwnie, jestestwo nimi obdarzone może przez ów [ruch] wiele działać i doznawać, oraz być samo w prawdzie i błędzie. [...] Jeżeli więc wyobraźnia [...] jest [...] istotnie tym, co powiedzieliśmy, można będzie ją zdefiniować: ruch wywołany przez aktualne postrzeżenie. A ponieważ wzrok

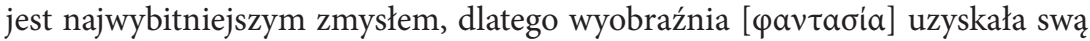
nazwę od światła [ $\varphi$ óoc], bez światła bowiem jest niemożliwe widzenie. Dzięki

${ }^{5}$ Zob. Arystoteles, O duszy, tłum. P. Siwek, Warszawa 1972, ks. 3, zwł. 425a-429a oraz przyp. 51, s. 180 , przyp. 66 , s. $191-192$. 
tej okoliczności, że wyobrażenia trwają [w osobniku] i są podobne do postrzeżenia, zwierzęta wykonują pod ich wpływem wiele czynności; jedne ponieważ brak im rozumu, drugie ponieważ ich rozum jest niekiedy przyćmiony namiętnością, chorobami lub snem - jak to ma miejsce u ludzi ${ }^{6}$.

Podobnie rozumieją naturę wyobraźni i wyobrażeń stoicy: jest to według nich ruch spowodowany przez wrażenie $w$ narząazie zmysłu, przenoszący się z niego na całą resztę ciała. Ponieważ ciała i rzeczy określają oni jako pola toniczne o specyficznych wartościach napięcia (eutonii) pomiędzy cząstkami skupianej w nich materii, fantazje burzą wzory takich pól. Zmieniając swą wyjściową wartość, eutonia staje się atonią (afektem), nietypowym stanem ciała, destruktywnie wpływającym na naszą zdolność osądzania wszystkiego, co nas otacza i co się z nami dzieje, a więc szkodliwym dla poznania i myślenia ${ }^{7}$. Stoicy o wiele bardziej surowo niż Arystoteles, który sądził, że rozum tylko niekiedy bywa przez nie przyćmiony, oceniają wyobrażenia. Stale przecież postrzegamy coś naszymi pięcioma zmysłami i bez przerwy, nawet podczas snu, przez nasze ciała przepływają pobudzenia i wspomnienia, ruchy i ich echa, docierając aż do serca, siedziby centralnego organu duszy. Stamtąd wraz z krwią rozlewają się po całym ciele i 'jak polip’ sięgają do wszystkich organów ciała. Dusza bądź umysł [ $\pi v \varepsilon u ̈ \mu \alpha]$, czyli niezwykle subtelna materia przemieszana z cząstkami ciała, podlega wszystkiemu temu, co je spotyka. Ostatecznie to ona postrzega zmiany $\mathrm{w}$ ciele albo na jego granicy - zniewalające (kataleptyczne) bądź niedokładne (akataleptyczne) wyobrażenie [ dzaj wyobrażeń, zwany też fantazją imaginacyjną, mamy dziś zwykle na myśli mówiąc o wyobrażeniu.

Stoicka doktryna moralna zaleca skupienie uwagi umysłu na jednej tylko kwestii, mianowicie czynieniu użytku $\mathbf{z}$ wyobrażeń. Człowiek nie ma bowiem możliwości unikania ich - chyba, że zamiast życia, wybierze śmierć. Wyobrażenia powstają w nas nieustannie; naszym zadaniem jest odróżniać je i pomimo ich obecności utrzymywać duszę w działaniu (eutonii), dbać o zachowanie jej źródłowego napięcia. Wyobrażenia, czyli zmiany uchwycone w ciele lub na jego granicy, mogą być obojętne, pożyteczne i szkodliwe ze względu na trwanie człowieka przy życiu, integralność i zdrowie jego ciała. Uwagę naszą powinny skupiać tylko postrzeżenia odnoszące się do zdrowia

${ }^{6}$ Arystoteles, O duszy, ks. 3, rozdz. 3, 428b-429a, s. 89-91. Znak / wskazuje koniec stronicy.

${ }^{7} \mathrm{O}$ ujęciu natury w filozofii stoickiej zob. J. Christensen, Esej o jedności filozofii stoickiej, tłum. M. Bardel, Warszawa 2004. 
i życia; te, które nie wiążą się z ich utrzymaniem należy nauczyć się ignorować. Rozróżniania rodzajów fantazji może dokonywać dusza pozostająca w stanie eutonii, będąca rozumem, a nie afektem, atonią. Atonia duszy sprawia, że nie działa ona w zwykły dla siebie sposób, lecz doznaje działania ze strony innych pól tonicznych, nie rozumuje, a więc nie wyjawia pełni swej istoty, jakby nie istnieje. Bierność duszy ( $\pi \dot{a} \theta 0 \varsigma$ ) to stan najwyższego jej poruszenia, wstrząśnienia wyrażającego się zwykle gwałtownym zachowaniem człowieka. Gdy niezwykłe jej poruszenie mija i dusza w końcu wraca do równowagi, odnajduje właściwy sobie tonos i znów może czynić, co do niej należy: rozumowo odróżniać wyobrażenia.

Dusza, która pragnie rozumować w skupieniu niezakłóconym fantazjami, szuka dla ciała miejsca, gdzie nie będzie ono doznawać gwałtownych zmian stanu i położenia. Tego rodzaju spokój, ámádecıa, prócz nazwy niewiele ma wspólnego z apatią. Dąży się do niego świadomie, stosując ćwiczenia specjalnie opracowane dla każdego adepta, podczas gdy apatia zwykle sama ogarnia człowieka i poddaje go swemu działaniu.

Przykry autobusowy incydent rozpatrywany z punktu widzenia zaproponowanego przez Arystotelesa można zinterpretować na przykład tak: każdy $\mathrm{z}$ pasażerów wystawiony $\mathrm{w}$ tłoku na działanie wielu różnorodnych i niekoniecznie przyjemnych doznań kumuluje w ciele aktualne postrzeżenia, nakładające się na ślady podobnych, dopiero co minionych wrażeń. Im dłużej trwa taka podróż, tym silniej odciskają się w ciałach i umysłach uczestników powtarzające się wrażenia. Kobieta, przy każdym szarpnięciu sprzęgła uderzana plecakiem stojącego przed nią studenta, cierpiała w tłoku, znosząc biernie przykre doznania. Uświadomiwszy sobie, że czeka ją jeszcze długa podróż, najwyraźniej zniecierpliwiła się na myśl, iż do końca będzie zmuszona znosić poszturchiwania. Antycypowanie szeregu takich zdarzeń mogło wywołać w niej nie-cierpliwą, „namiętną” potrzebę uwolnienia się z opresji. W jaki sposób? Zauważmy, że nasza bohaterka nie postanowiła wysiąść wcześniej ani nie zmieniła miejsca, przesuwając się na przykład bliżej drzwi lub okna; nie poprosiła też młodego człowieka, aby zdjął plecak i trzymał go w ręku, tylko postąpiła tak, jak może działać człowiek, kiedy straci nad sobą panowanie.

Pytanie o to, co wyobraża sobie współpasażer, poddany - tak jak wszyscy - tej samej opresji jazdy w nieludzkim ścisku, w żaden sposób nie usunęło problemu, przeciwnie, do już istniejącego dodało nowy. W tłoku, kiedy każdy stara się ignorować wymuszone (fizyczne i psychiczne) przekroczenie przez obcych swej prywatnej i intymnej przestrzeni, rozgniewana kobieta dokonała 
aktu odwetu za naruszanie swej nietykalności: dopuściła się inwazji wprost do obszaru, do którego zwykle nie dopuszcza się obcych ludzi - do najintymniejszej sfery wyobrażeń.

Reakcja młodego człowieka była natychmiastowa. Jej gwałtowność, niewyczuwalną co prawda w tonie głosu, lecz uchwytną w szybkości reakcji na atak wycelowany w jedyny obszar, który podczas tej podróży udało mu się zachować nienaruszony, można rozumieć jako akt obrony siebie samego, dokonany niemalże przez zaprzeczenie treści spostrzeżenia, odparcie go. Że pani tu nie ma: skoro nie ma osoby, nie było też ataku; co prawda jest autobus, zużyte sprzęgło, podła pogoda, nieludzki tłok, ale wszystko to tylko przejściowe, fizyczne okoliczności, powtarzające się dwa razy dziennie; to rutyna, przykra, lecz dająca się znieść pod warunkiem, że można przetrwać tę podróż wycofując się do własnego wnętrza, gdzie każdy z nas jest wolny. Inna sprawa, że odpowiedź ta wyraża również infantylne życzenie, ̇̇eby atakująca znikła. Gdyby nie było tu jej głosu, domagającego się natychmiastowej relacji ze szczegółów przebiegu intymnego procesu psychicznego, który został przerwany jej krzykiem, wyobrażenia lub fantazje pochłaniające młodego człowieka podczas podróży mogłyby trwać bez względu na pozostałe okoliczności - do nich zdążył się już przyzwyczaić.

W zachowaniach obydwu opisanych osób widać wyraźnie rysującą się tendencję do pozostania w osiągniętym stanie. To coś innego, niż stoicka dążność samozachowawcza, czyli naturalna skłonność ciała do pozostania przy życiu w stanie integralności organizmu. Młody człowiek wypracował sobie sposób trwania w tłoku, starsza pani - przekonanie o nienaruszalności praw należnych jej płci i wiekowi oraz sposób dbania o ich respektowanie. Żadne z nich nie zostało podczas jazdy wystawione na niebezpieczeństwo, które uruchomiłoby w nich stoicką dążność samozachowawczą, obydwoje jednak przejawili tendencję do zachowania stanu, w jakim rozpoczęli podróż. Skłonność ta uwidacznia się na co dzień o wiele częściej, aniżeli potrzeba chronienia życia i zdrowia, a mimo to w rozważaniach antycznych myślicieli zeszła ona na dalszy plan.

W czasach nieco nam bliższych zwrócił na nią uwagę Spinoza, przypisując ją przy tym nie tylko żywym jestestwom, ale wszystkim rzeczom, których status określił mianem modyfikacji substancji. Jego poglądy, wyrażane językiem stojącym w opozycji do przesiąkniętej arystotelizmem scholastyki, mają ścisły związek z doktryną stoicką, dlatego przywołanie obydwu tych tradycji pomoże jaśniej nakreślić osobliwość ujęcia kwestii wyobraźni w Etyce. 
Spinozjańskim modyfikacjom nie przysługuje jednostkowe, odrębne istnienie, takie, jakie przynależy bytom Arystotelesa; powinniśmy je rozumieć w sensie przejawów jedynego, niepodzielnego i nieskończonego bytu8 W szeregu twierdzeń trzeciej części Etyki, z ogólnego prawa, mówiącego, że „każda rzecz, o ile jest sama w sobie [in se est], usiłuje pozostawać w swym istnieniu [in suo esse perseverare conatur]"', Spinoza wyprowadził szczegółowe wnioski dotyczące człowieka i jego zachowania. O tym, jak istotna jest ta reguła, świadczy tw. 7 z tej samej części, mówiące wyraźnie, że „dążność każdej rzeczy do pozostawania w swym istnieniu nie jest niczym innym, jak aktualną [czyli działającą - przyp. J. Ż.] istotą samej tej rzeczy" ${ }^{10}$ i nie odnosi się do jakiegoś określonego, skończonego czasu, gdyż w żadnej modyfikacji substancji nie zawiera się nic, co byłoby sprzeczne z nią samą i dążyło do jej unicestwienia. Powyższe zasady regulują istnienie, działania i stany pasywne ciał i umysłów, dlatego o duszy można powiedzieć, że „zarówno, o ile posiada idee jasne i wyraźne, jak i o ile posiada mętne, usiłuje pozostawać w swym istnieniu niejako $\mathrm{w}$ trwaniu nieokreślonym i jest świadoma tej dążności”" ${ }^{\prime 1}$. Co istotne, umysł, idea ciała, nie zmierza do prawdy, nie pragnie pewności ani doskonałości bez względu na to, co dzieje się z jego ciałem i wokół niego. W każdym momencie - jak gdyby mocą jakiejś dziwnej inercji - gotów jest pozostać tym, czym się stał. Gdyby mógł trwać sam w sobie, nie podlegając wraz ze swym ciałem pobudzeniom i nie postrzegając obecności innych idei, kontemplowałby jego stan w nieruchomym zadowoleniu, niczego innego nie pożądając.

Znana z Etyki zasada paralelizmu modi różnych atrybutów mówi, że wszystko to, co substancja wyraża przez modi jednego ze swych atrybutów, ujawnia też $\mathrm{w}$ pozostałych swoich atrybutach, w każdym na właściwy mu sposób. Skoro poznanie nasze obejmuje ekspresję substancji zarówno w rozciągłości, jak i w myśleniu (tzn. w postaci rzeczy rozciągłych i pojęć (idei) tych rzeczy), to modi substancji możemy rozważać tak, jak będzie nam je najłatwiej uchwycić - albo jako sposoby istnienia rzeczy, albo jako treści niewidzialnych idei. Bez wątpienia czytelnikom współczesnym Spinozie łatwiej było pojmować prawidłowości, które mogli śledzić odwołując się do swych

\footnotetext{
${ }^{8}$ Wszystkie niezbędne założenia i twierdzenia na temat rzeczy (modi substancji) zostały wprowadzone w dwóch pierwszych księgach Etyki, zob. B. Spinoza, Etyka w porządku geometrycznym dowiedziona, tłum. I. Myślicki, Warszawa 1954.

9 Tamże, cz. 3, tw. 6, s. 152.

10 Tamże.

${ }^{11}$ Tamże, tw. 9, s. 153-154.
} 
spostrzeżeń zmysłowych, dlatego też w Etyce znajdujemy przykłady odnoszące się przede wszystkim do modi danych w atrybucie rozciągłości substancji, to jest do ciał i nieożywionych przedmiotów.

Ułatwienie to kryje w sobie jednak pułapkę, którą trudno będzie ominąć w naszym naturalnym nastawieniu, utrwalającym powszechne, metafizyczne poglądy na temat podstaw wszystkiego, co jest nam dane. Przywykliśmy myśleć o rzeczach według schematu kategorii Arystotelesa ${ }^{12}$, a to znaczy, że na mocy tego nawyku przesądzamy o autonomicznym, jednostkowym charakterze przedmiotów w naszym otoczeniu, przekonani, że swoją odrębność zawdzięczają podzielnej na porcje materii. Tymczasem według Spinozy modi czerpią zasadę jednostkowienia z samej tylko niepodzielnej substancji, która nie jest materią. Przekształca się ona bezustannie i to cała na raz, obejmując jednym aktem nieskończoność wszelkich swoich pobudzeńn ${ }^{13}$. Nie ma przy tym znaczenia fakt, że postrzegamy jej przemiany tak, jak gdyby składały się one z pojedynczych ogniw łańcucha następujących po sobie zdarzeń. Nasz sposób widzenia wynika koniecznie z oczywistej i prostej reguły, mówiącej, że część nie obejmuje całości, której jest częścią; odwrotnie, jest przez nią ujmowana. Umysł ludzki, czyli przejaw substancji rozważanej z punktu widzenia myślenia (to znaczy idea ludzkiego ciała) nie obejmuje substancji swoim poznaniem przedmiotowym. Może ujmować ją wyłącznie formalnie, jako logiczny warunek, umożliwiający złożenie wielości poznawanych idei $\mathrm{w}$ jedność systemu poznania ${ }^{14}$. Nie należy więc pojmować rzeczy, danych nam w postaci wrażeń zmysłowych, jakby były odrębnymi istnieniami, tylko stale szukać całości, podstawy zjawisk, ukazującej się nam poprzez nie, jednocześnie, na wiele sposobów.

Jednym z możliwych przybliżeń tego stanu rzeczy jest obraz powierzchni morza, na której potrafimy wyróżnić grzbiety pojedynczych fal - choć

\footnotetext{
${ }^{12}$ Według Spinozy ten typ metafizyki mógł utrwalić się przede wszystkim ze względu na stosowalność jej pojęć w praktycznym, techniczno-zmysłowym działaniu człowieka, skupiającym się na tropieniu odległych następstw dobrze znanych zjawisk. Rzutowanie celowości charakterystycznej dla ludzkiego działania na całość natury, a następnie, pod postacią przyczyny celowej, wpisanie jej w podstawy kosmicznego ładu, to kolejny powód, dla którego ten sposób myślenia trudno wyrugować z umysłów.

${ }^{13}$ Spinoza powie wprost, że nie istnieje nic oprócz substancji i jej modi, a to znaczy, że pozostałym pojęciom jego filozofii przysługuje status bytów myślnych (entia rationis), czyli terminów utworzonych w celu porządkowania słów i pojęć. Należy do nich m.in. 'atrybut'. Zob. Etyka, cz. I, tw. 15 dow., s. 22.

${ }^{14} \mathrm{~W}$ sensie formalnym idea substancji pełniłaby więc w filozofii Spinozy podobną rolę, jak idee regulatywne w myśli Kanta.
} 
widzimy je oddzielone od siebie powierzchnią wody, wiemy, że ów obraz przedstawia nam samo morze $\mathrm{w}$ jego niekończącym się ruchu, kołysaniu i trwaniu, czyli w jego istocie, gdy rozważamy je jako rzecz rozciągłą. To, co widzimy, zależy jednak od naszych możliwości postrzegania i rozumienia, od perspektywy, którą możemy przyjąć. Oglądane od środka, tak jak widzą je delfiny i ryby, morze w niczym nie przypomina monstrualnego zwierzęcia, po którego połyskliwej skórze przebiegają wciąż dreszcze - a tak być może widzą je ptaki.

Gdy pomyślimy o morzu, mając je na względzie jako całość, rozumiemy, że każda jego fala, dowolna zmarszczka na jego powierzchni, lokalnie wyraża nieustający proces przemian tej całości. Jednak fale morskie mocują się również z niebem; tu uginają się pod podmuchem wiatru, aby tam wypiętrzyć się i zagarnąć haust powietrza pod taflę wody. Dlatego obraz morza jako przybliżenie sposobu istnienia Spinozjańskiej substancji jest nie w pełni adekwatny: będąc nieskończoną, nie graniczy ona z niczym, nie ma powierzchni, środka ani peryferii. My, jej przejawy, trwamy zawsze w jej wnętrzu, jak ryby głębinowe w oceanie, nigdy nie docierając do jej granic, gdyż nieskończoność ich nie posiada.

Immanentyzm właściwy dla Etyki umiejscawia nas zawsze pośród rozciągłych przejawów natury, a nie ponad nimi. Rozważając ciało ludzkie, powinniśmy stale dbać o to, żeby nie tracić z oczu jedności natury, której jest ono zaledwie lokalnym wyrazem. Można co prawda patrzeć na nie jak na rybę, wymuszającą swym ruchem ruch mas wody i dostrzec, jak przecinając głębinę, sprawia ona, że woda rozstępuje się wokół jej ciała. Można też skupić spojrzenie na wodzie, a wówczas zauważymy, że w każdym mgnieniu oka dokładnie przywiera do wszystkich zanurzonych w niej powierzchni i odtwarza w sobie ich kształty. Czy ryba płynie w wodzie, rozsuwając własnym ciałem jej masy, czy przeciwnie - unoszące ją cząsteczki wody roztrącane jej pyskiem, rozstępują się przed nią i skupiają za nią, popychając ją w wolne miejsce?

Zauważmy, że powyższy dylemat wynika jedynie ze sposobu, w jaki nasza ratio, traktująca rozłącznie obydwa człony alternatywy, zwykła wnioskować i porządkować pojęcia, ujmujące spostrzeżenia naszych zmysłów. Wydaje się jednak, że poza językiem, albo, jak powiedziałby Spinoza, w samym atrybucie rozciągłości natury, alternatywę rozłączną zastępuje koniunkcja: przecież pływanie możliwe jest tylko wtedy, gdy spotykają się zarazem i ryba, i woda. Wobec tego wszystkie trzy wymienione przejawy natury, morze, ryba i pływanie współdeterminują się, określają się wzajemnie, tak, że nie sposób 
zrozumieć ich abstrakcyjnie, w oderwaniu od siebie. Gdy uwzględnimy ten punkt widzenia, wówczas substancja, nieskończona jedność, jawić się nam zacznie jako taniec poruszających się wzajemnie, adekwatnie dopasowanych do siebie istot, lub może lepiej - relacji, ukonstytuowanych przez ruch i spoczynek, które $\mathrm{w}$ różnych punktach nieskończonej rozciągłości wyrażają się jako różne proporcje ${ }^{15}$.

Z-myślenie obrazu substancji w postaci morza oraz tezy, dotyczące sposobu rozumienia znaczenia tego pojęcia ${ }^{16}$ pomogą nam uchwycić problem, jakim w Etyce stała się wyobraźnia ludzka. O tym, że jest to problem, najwyraźniej świadczy fakt, iż wyobraźnia (imaginatio), wyobrażanie (imaginare) i obraz (imago) należą do pojęć wymienianych niemalże tak często, jak afekt ${ }^{17}$, termin, któremu poświęcono trzy spośród pięciu ksiąg tego dzieła. Przyglądając się sposobowi wprowadzenia pojęcia wyobraźni do tekstu Etyki, zauważymy, że Spinoza złamał przyjęte wcześniej reguły budowania systemu dedukcyjnego i nie umieścił go w żadnym z zestawów definicji proponowanych na początku każdej księgi.

Tymczasem o tym, że celem dzieła jest rozrachunek z nieokiełznaną ludzką wyobraźnią, dowiadujemy się już na początku I księgi, gdzie zostały wyliczone błędy, popełniane powszechnie przez ludzi nie posiadających wiedzy o przyczynach rzeczy. Wymyślają oni sobie (imaginatur) i gmatwają (loquentes fingunt) bez oporu ze strony umysłu naturę boską i ludzką, ludzką i zwierzęcą, przypisują bogom afekty, roślinom cechy ludzkie, a ludziom zwierzęce ${ }^{18}$. Niepodzielność substancji, a więc jej jedność i jedyność, nie zaś złożoność z odrębnych ciał, wydaje im się niepojęta, gdyż nie odróżniają wyobraźni od rozumu ${ }^{19}$, „a doprawdy przypuszczanie, że substancja cielesna składa się z ciał, czyli części, jest równie niedorzeczne, jak [przypuszczanie],

${ }^{15} \mathrm{~W}$ taki sposób, jako proporcję ruchu i spoczynku, Spinoza określił w Etyce ciała rozciągłe; zob. cz. II, tw. pomocnicze V, s. 87: „Jeżeli części składające się na jednostkę zwiększają się lub zmniejszają, jednakże w takiej proporcji, że wszystkie zachowują ten sam, co przedtem, stosunek wzajemny ruchu i spoczynku, wówczas jednostka także zachowa swą poprzednią naturę bez jakiejkolwiek zmiany swego kształtu" [wyróżnienia w tekście - J. Ż.].

${ }^{16}$ Pojęcie to zostało odróżnione w Etyce od wyobrażenia i fikcji. Spinoza nadaje mu pozytywne znaczenie, gdyż zmyślanie w większym stopniu niż fikcja i wyobrażenie zależy od ratio i pozostaje pod jej wpływem. Ten quasi-racjonalny charakter zmyślenia podkreśliłam wydobywając rdzeń słowa, 'myśl'.

${ }_{17}$ Zob. E. Giancotti Boscherini, Lexicon Spinozanum, A-K, La Haye 1970, Affectus - s. 36-47, Imaginari, Imaginatio, Imago - s. 509-518.

${ }_{18}$ Zob. Etyka, cz. I, tw. 8, przyp. II, s. 10.

${ }_{19}$ Tamże, tw. 15, przyp., s. 26; w oryginale chodzi o imaginatio i intellectus. 
że ciało składa się z płaszczyzn, płaszczyzny z linii, linie wreszcie - z punktów"20.

Rozróżnienie to okazuje się jednak trudne nawet dla filozofa - pojęcie wyobraźni znajdujemy dopiero w drugiej części Etyki, ukryte w przypisie do tw. 17, gdzie możemy przeczytać, co następuje:

żeby trzymać się utartych wyrażeń, pobudzenia ciała ludzkiego, których idee przedstawiają nam ciała zewnętrzne, jakby były nam obecne, będziemy nazywali obrazami (imagines) rzeczy, chociaż nie odpowiadają one kształtom rzeczy. Kiedy zaś dusza w ten sposób rozważa ciała, powiemy, że sobie wyobraża $\left(\right.$ imaginari) ${ }^{21}$.

Obrazy (imagines) to pobudzenia ciała ludzkiego (corporis humani affectiones), nie odpowiadające kształtom rzeczy zewnętrznych, natomiast przedstawiające te rzeczy tak, ,jakby” były nam obecne - Spinoza nie kusi się o własną definicję wyobraźni, tylko przywołuje „utarte wyrażenie” zaczerpnięte z tradycji arystotelesowskiej, gdzie wyobrażeniem nazwany został ruch, ślad w ciele, spowodowany postrzeżeniem rzeczy zewnętrznej, na tyle wyraźny lub, jak powiadamy - niezatarty, by trwając w nas, wywołał affectio, poruszenie, echo przypominające źródłowe podrażnienie oka przez światło, odbite od faktycznie oglądanej rzeczy. Spinozjańskie „jakby” dołączone do opisu znaczenia słowa „obraz” podkreśla luźność relacji między członami porównania, odnoszącego do siebie dwa typy pobudzeń substancji: ciała i duszę. „Utartego wyrażenia” nie należy traktować jako definicji. Jednak nie mając jej, możemy jedynie przenośnie odnieść do ciała schemat (opis) procesu zachodzącego w duszy, podczas gdy ona sobie coś wyobraża. Faktycznie bowiem, a nie metaforycznie, tym, co wiąże procesy mentalne i cielesne, jest substancja, a nie ratio i język. Widać to wyraźnie w strukturze przytoczonego tu opisu - jego oś stanowi słowo obecność (praesentia), istotowo odnoszące się do bezczasowej substancji, czyli tego, co jest w sobie i co powinniśmy rozumieć per se, bez uciekania się do pomocy innych pojęćc2 . Spinoza w zasadzie nie potrzebuje tu metafory, ponieważ w jego myśleniu zastępuje ją o wiele mocniejsza reguła paralelizmu modi wszystkich atrybutów substancji; dlatego o przemianach w ciele i umyśle ludzkim może powiedzieć unum et idem sunt. Przenośni potrzebują jednak jego czytelnicy.

\footnotetext{
${ }^{20}$ Tamże, przyp., s. 25; wyróżnienie w tekście - J. Ż.

${ }^{21}$ Tamże, s. 95.

${ }^{22}$ Tamże, cz. I, def. 3, s. 3.
} 
Nosimy w sobie nieokreśloną ilość takich śladów zetknięcia się własnego ciała $\mathrm{z}$ innymi, zewnętrznymi rzeczami w rozciągłości. Wszystkie trwają w nas czas jakiś i w końcu wybrzmiewają jak echo. Ich idee, przedstawiając swe istoty w goszczącym je umyśle, będącym również ideą swego ciała, mieszają się i łączą, tak, że w końcu umysł posiada wiedzę o sobie jako pobudzonym przez idee, nie zaś o samych tych ideach ani tym bardziej nie o sobie samym. Nie może być inaczej, bowiem jako idea ciała poznaje siebie tylko o tyle, o ile poznaje idee pobudzeń swojego ciała ${ }^{23}$, a te zawierają jako swe przyczyny idee ciał zewnętrznych. Tak więc o tym, że oprócz mojego ciała istnieją także inne, zewnętrzne rzeczy, dowiaduję się poprzez idee pobudzeń własnego ciała; inaczej mówiąc, nasza wiedza o świecie zewnętrznym zapośredniczana jest stale przez samowiedzę, jaką mamy o sobie, gdy jako idee zwracamy się ku swym istotom odkrywając, że są one ideami ciał. Samowiedza ta, formalnie rzecz ujmując, ujawnia się umysłowi jako idea idei. Przedmiotowo obejmuje ona idee ciał zewnętrznych, pobudzających moje własne ciało, stanowi więc coś na kształt informacji o "lokalnym” stanie substancji, a to znaczy, że nie może być ideą prawdziwą, tylko wyobrażeniem.

Powiadam wyraźnie - podkreśla Spinoza - że dusza nie posiada ani o sobie samej, ani o swym ciele, ani o ciałach zewnętrznych wiedzy adekwatnej, lecz tylko [wiedzę] mętną, ilekroć poznaje rzeczy w zwykłym porządku przyrody, to znaczy, ilekroć z zewnątrz, mianowicie przez przypadkowy zbieg rzeczy, zostaje zdeterminowana do zajęcia się tym lub owym, a nie ilekroć od wewnątrz, mianowicie przez to, że rozpatruje jednocześnie wiele rzeczy, bywa zdeterminowana do rozumienia ich zgodności, różnic i przeciwieństw. Ilekroć bowiem bywa determinowana $\mathrm{z}$ wewnątrz $\mathrm{w}$ taki czy inny sposób, wówczas patrzy na rzeczy jasno i wyraźnie ${ }^{24}$.

Gdyby odnieść powyższe stwierdzenia do wprowadzonej wcześniej metafory morza i żyjących w nim ryb, należałoby zauważyć, że o ich poruszaniu się pod powierzchnią wody nie sposób mówić inaczej, jak o całości, którą rozpatrujemy jako równoczesny ruch otoczenia i żywego ciała. Stanowią one doskonałe korelaty, poruszające się razem i wywierające na siebie tak decydujący, determinujący wpływ, że nie ma sensu rozpatrywać zmiany w położeniu jednego tylko obiektu, wody albo ryby. Nie istnieje pływanie, gdy nie ma poruszania wody; gdy ono zachodzi, woda porusza to, co ją poruszyło. Podob-

\footnotetext{
${ }^{23}$ Tamże, cz. II, tw. 23, s. 100.

${ }^{24}$ Tamże, tw. 29 przyp., s. 106-107.
} 
nie rzecz się ma z poznaniem: gdy w umyśle brak idei ciała zewnętrznego, wkraczającej do niego, by ogłosić w nim swe własne treści, nie ma w nim pobudzeń, obrazów rzeczy, wyobrażeń, a więc „dusza ludzka nie jest w żaden sposób pobudzana przez ideę istnienia tego ciała, czyli w żaden sposób nie poznaje istnienia tego ciała zewnętrznego"25. Jednakże obecność takich idei tworzy w umyśle wyobrażenia rzeczy zewnętrznych, nakładające się na ślady dopiero co minionych pobudzeń - zatem poznanie najbliższego otoczenia to gmatwanina wyobrażeń, kłębiących się w zmąconej, ciągle od nowa pobudzanej idei ciała. Wiedza o nim nigdy nie może być adekwatna, inaczej mówiąc, idea jego idei nie nadąża formować się dość sprawnie, aby dorównać zmieniającym się wciąż proporcjom ruchu i spoczynku wszystkich jego części. To stwierdzenie nie napawa optymizmem: wynika z niego bowiem, że za życia, zwłaszcza jeśli wypełnimy je intensywnymi doznaniami, nie poznamy ani siebie, ani natury, ani też naszych bliźnich; możemy zamiast tego spodziewać się, że upłynie nam ono w słodko-gorzkim zamęcie pragnień i niespełnień. Spinoza nie pozostawia nam w tej kwestii żadnych złudzeń; może tylko, zdając sobie sprawę z tego, jak twardo brzmią jego słowa, nie eksponuje swej tezy i ukrywa ją w dodatku do cytowanego wyżej twierdzenia, gdzie pisze: „o ile dusza ludzka wyobraża sobie ciało zewnętrzne, o tyle nie ma o nim adekwatnej wiedzy"26.

Wyobrażenia jako ślady pobudzeń odtwarzane przez umysł stanowią ważną podstawę pamięci. Bez niej nie byłoby możliwe rozpoznanie aktualnego doznania, które identyfikujemy, porównując je ze śladami minionych wrażeń i sprawdzając, w jakim stopniu są do nich podobne. Spinoza napisze, że „jeżeli ciało ludzkie było kiedyś pobudzone przez dwa lub więcej ciał jednocześnie, to dusza, wyobrażając sobie później jedno z nich, przypomni sobie od razu i inne" ${ }^{27}$, nawet jeśli nie ma i nie było między nimi innego związku, jak tylko współwystępowanie. Od współdziałania wyobraźni, postrzegania i pamięci zależy ludzka zdolność uczenia się mowy, tak oto zilustrowana w przypisie do powyższego twierdzenia:

dusza od pomyślenia o jednej rzeczy przechodzi (incidit) natychmiast do pomyślenia o innej, nie mającej z tamtą żadnego podobieństwa: tak np. Rzymianin od pomyślenia wyrazu "pomum" natychmiast przechodził do pomyślenia o owocu, który nie okazuje żadnego podobieństwa do owego artykułowanego

\footnotetext{
${ }^{25}$ Tamże, tw. 26, dow., s. 103.

${ }^{26}$ Tamże.

${ }^{27}$ Tamże, tw. 18, przyp., s. 95.
} 
dźwięku i nie ma z nim nic wspólnego poza tym, że ciało tegoż człowieka często bywało pobudzane przez obydwa, to znaczy, że tenże człowiek często słyszał wyraz „pomum” wtedy, gdy widział sam owoc. W ten sposób każdy przechodzi od jednej myśli do innej stosownie do tego, jak przyzwyczajenie uporządkowało w jego ciele obrazy rzeczy. Tak np. żołnierz, ujrzawszy ślady kopyt końskich na piasku, przechodzi natychmiast od pomyślenia o koniu do pomyślenia o jeźdźcu, stąd zaś do myśli o wojnie itd.; rolnik zaś od pomyślenia o koniu przechodzi do pomyśleniu o pługu, o roli itd..$^{28}$

O ciele ludzkim, jeśli rozważamy je jako takie, wiemy, że tak samo jak każda rzecz, usiłuje ono trwać w swym istnieniu. To samo prawo odnosi się również do jego idei, czyli ludzkiego umysłu. Spinoza wyraźnie podkreśla: o ile modi te rozważamy same w sobie, a nie tak, jak dotąd, w odniesieniu do ciał zewnętrznych i ich idei. Gdyby umysł i ciało mogły istnieć całkowicie in se, tak jak nieskończona substancja, która z niczym nie graniczy, gdyby nie opierały się i nie podlegały pobudzeniom ze strony innych ciał i idei, wówczas istniałyby, nieruchome i niezmienne, wyrażając swe istoty: ciało wartość proporcji ruchu wobec spoczynku swych części, jego idea - czysty wzór tej proporcji, r/s. W naturze tak jednak nie jest; toteż ciała otoczone przez inne ciała dążą do zachowania swego istnienia, a ich idee, goszcząc w sobie idee ciał zewnętrznych, usiłują nie zapomnieć swego źródłowego „wzoru”. I jedne, i drugie są w istocie pożądaniem trwania, w każdej chwili narażonego, jeśli nie na unicestwienie, to na przekształcenie owego „wzoru”, tak radykalne, że przestanie on przypominać swą pierwotną postać.

Jeśli w nieskończonej naturze żadne ciało nie „posiada” istoty, swego „twardego rdzenia”, który trwając w nim sprawia, że jest ono tym, czym jest i bez czego nie może być ani być pojęte, gdyż każde zaledwie dąży do zachowania swego trwania zagrożonego naporem innych ciał; jeśli w tym dążeniu, w zmaganiu z całą nieskończoną „resztą” natury wyraża się istota ciała i jego idei $^{29}$, ich akt, czyli działanie, to natura pozostanie dla nas zawsze niepoznawalna. Patrząc wokół z perspektywy „własnego ciała”, tego dziwacznego ob-

\footnotetext{
${ }^{28}$ Tamże, s. 96-97.

${ }^{29}$ Współczesna neurologia i neuropsychologia określa ten proces mianem „mapowania” przez umysł wnętrza ciała, zarówno jego trzewi, jak i wzajemnego położenia korpusu, głowy i kończyn, temperatury organów wewnętrznych i powierzchni skóry, nasycenia krwi tlenem i substancjami przemiany materii, a także substancjami odżywczymi. Umysł, oprócz dostępnych nam i znanych procesów mentalnych umożliwiających komunikację, wykonuje całe mnóstwo czynności zmierzających do zachowania względnej równowagi metabolicznej ciała w jego otoczeniu. O ideach filozofii Spinozy, prekursorskich względem tych badań, pisał ob-
} 
szaru przestrzeni, zapisanego śladami doznań słabości i eksplozji mocy, „jego dusza" ujmuje i zachowuje idee wszystkich tych zdarzeń według opisanej wyżej zasady ich współwystępowania. Umysł to w ogromnej mierze pamięć ciała oraz jego okolic, bezładne składowisko pogmatwanych idei, z którego aktualne postrzeżenia raz po raz przyciągają ku sobie coś, co zdaje się być podobne do „obrazu”, jaki rzecz zewnętrzna utworzyła właśnie w zmysłach.

Do ciała należą także słowa, wypowiadane, słyszane, czytane i pisane przez nie, towarzyszące wrażeniom jego zmysłów i współujmowane wraz z nimi przez jego pamięć. Treści i znaczenia słów, czyli pojęcia (idee) stanowią mentalne korelaty fizycznych zdarzeń. Najczęściej mętne i splątane, tak jak pobudzenia ciała, wypełniają wyobraźnię i zalewają umysł niemal niekończącym się strumieniem skojarzeń. Spinoza przypisuje słowom pewną własność, odróżniającą je od konceptów umysłu, to znaczy pojęć utworzonych w celu poznawania rzeczy wiecznych, takich, które trwają w sobie, wyrażane przez niezmienne istoty, jak idee kwadratu, trójkąta, substancji i im podobnych. O różnicy tej pisał już w Traktacie o uzdrowieniu rozumu: „Słowa same [...] stanowią część wyobraźni; znaczy to, że zmyślamy sobie mnóstwo pojęć stosownie do tego, jak słowa bezładnie układają się nam w pamięci na skutek jakiegoś stanu ciała" ${ }^{30}$. Słowa wyrażające pobudzenia ludzkich ciał powstały wcześniej niż pojęcia rozumowe, ujmujące istnienie całej natury jako nieskończonej i niepodzielnej jedności

widać to jasno stąd, iż temu, co tylko w rozumie, nie zaś w wyobraźni jest obecne, nadaje się pospolicie miana negatywne, np. bezcielesny, nieskończony itp. Podobnie wiele jakości, które naprawdę mają charakter pozytywny, wyraża się za pomocą określeń negatywnych i odwrotnie; należą tu takie określenia, jak: niestworzony, nieskończony, nieśmiertelny itp. A dzieje się tak z pewnością dlatego, że znacznie łatwiej wyobrazić nam sobie ich przeciwieństwa i te przeciwieństwa właśnie wcześniej ujawniły się pierwszym ludziom i zagarnęły dla siebie nazwy pozytywne ${ }^{31}$.

szernie A. R. Damasio w słynnej pracy Looking for Spinoza (wyd. polskie - W poszukiwaniu Spinozy, tłum. J. Szczepański, Poznań 2005).

${ }^{30}$ B. Spinoza, Pisma wczesne, s. 383, pkt 88.

31 Tamże, pkt 89. Uwaga dotycząca konstrukcji nazw pojęć i słów stanowi dodatkowy argument wspierający tezę o niemożności wyobrażenia sobie „braku” czegoś. Pojęcia rozumu zdolnego odrywać od siebie cechy (abstrahować) często zdaniem Spinozy zachowują w swojej strukturze ślad tej mentalnej czynności i zawierają negację: niepodzielność, nieskończoność, niezwykłość itp. Wyobrażenie (i nazwa tego, co wyobrażone) zawsze jest konkretne i „pełne”, 
Pisząc Etykę, Spinoza nie zmienił poglądu na naturę słów oraz ich związek z ciałem i wyobraźnią; uszczegółowił tylko swoje wcześniejsze wypowiedzi, dodając wzmianki o wielkości i materiii ${ }^{32}$, a także o celu, pięknie i brzydocie, dobru i złu, porządku i bezładzie, winie i zasłudze ${ }^{33}$. Na uwagę zasługuje przede wszystkim fragment przypisu, objaśniającego różnicę między wyobrażeniami i rozumieniem „materii” jako budulca lub podłoża, w którym formowane są rzeczy, ponieważ właśnie tu najjaśniej uwidoczniła się Spinozjańska opozycja wobec potocznego pojmowania natury, ukształtowanego na podstawie metafizyki Arystotelsa.

Dowiadujemy się więc, że „materia jest wszędzie ta sama, i że o tyle tylko rozróżniać w niej można części, o ile pojmuje się ją jako pobudzoną w rozmaity sposób, skąd też części jej dają się rozróżnić tylko modalnie, nie zaś realnie [tj. można wyróżniać w materii części nie o ile rozważa się ją w sobie, a tylko o ile rozważa się sposób, w jaki przedstawia się ona naszemu poznaniu]"34. Czym jest materia rozważana „w sobie”, nie zaś z punktu widzenia umysłu, czyli idei pewnego ciała, otoczonego i pobudzanego przez wiele innych rzeczy, wie ten, kto nauczył się odróżniać wyobraźnię od rozumu (intellectus).

Rzeczy należące do natury rozciągłej ujmujemy przede wszystkim zmysłami naszego ciała, w którym ślady ich spostrzeżeń łączą się z nowymi wrażeniami i razem ukazują się wyobraźni. Takie ujęcie jest dla nas najłatwiejsze, ale też i najbardziej pobieżne, "powierzchowne”, jak mówi o nim Spinoza. Nie możemy ogarnąć wzrokiem nieskończonej rozciągłości natury; skupiamy więc spojrzenie na pewnym jej fragmencie, na przykład na widoku powstającym w okiennej ramie jadącego autobusu. Obrazy migające nam przed oczami byłyby zupełnie niepojęte, gdybyśmy na magmę świateł nie rzutowali siatki słów, tnących ją na części i „wyłapujących” z ciągle zmieniającego się obrazu pewne jego przejawy, podobne do zjawisk oglądanych już wcześniej i powiązanych $\mathrm{w}$ pamięci ciała $\mathrm{z}$ brzmieniami lub obrazami konkretnych słów. Tak postrzegana przestrzeń w okiennej ramie ukazuje się nam wypełniona skończonymi pod względem wielkości, podzielnymi na określoną ilość części i złożonymi rzeczami. Odpowiednio napinając mięśnie oczu, potrafimy patrzeć przez szybę, którą częściowo zasłaniają pasażerowie, nie widząc

choć możemy zdawać sobie sprawę (co jest czynnością rozumową i może się wyrażać zgodnie z zasadami działania rozumu), że pozostaje „mgliste” i „niewyraźne”.

${ }^{32}$ Etyka, cz. I, tw. 15, przyp., s. 26.

${ }^{33}$ Tamże, tw. 33, przyp., s. 59; zob. też s. 60-61.

${ }^{34}$ Tamże, tw. 15, przyp., s. 26, podkreślenie w tekście - J. Ż. 
ich, a raczej nie angażując pamięci w proces przypominania sobie, dlaczego obraz przestrzeni za oknem jest zdeformowany. Czy można wyobrazić sobie również, że „nie ma tu”, przy tej szybie, osoby opartej o nią plecami i głośno domagającej się informacji o stanie wyobraźni jednego ze współpasażerów? Spinoza sugeruje, że konkretyzm wyobraźni mógłby podsunąć nam jedynie inny obraz, ukazujący na przykład widok z okna autobusu, albo postać innego pasażera, zasłaniającego fragment szyby - cokolwiek, co nie jest samym tylko brakiem. Wyobraźnia nie może zastąpić obrazu istniejącej rzeczy obrazem jej nieistnienia, chociaż rzeczy nie istnieją tak, jak je widzimy. Ponadto wyobrażanie sobie kieruje uwagę umysłu na ślady minionych jego spostrzeżeń, a nie na obrazy i treści idei, które aktualnie wkraczają do niego przez zmysły. Zatem młody człowiek - jeśli wcześniej nie spotkał owej gniewnej damy - nie mógł nosić w sobie śladów spowodowanych jej spostrzeżeniem, tym bardziej nie mógł odwołać się do śladów ich braku.

Ani brak, ani nadmiar, ani nawet umiar w odwoływaniu się do wyobraźni nie jest właściwą wskazówką, pozwalającą unikać konfliktów moralnych i niwelować już zaistniałe. Właśnie wyobrażanie sobie siebie „na czyimś miejscu”, kogoś w naszym, albo siebie w „cudzym położeniu” może dawać opłakane efekty, gdyż polega na wspomnianym wyżej składaniu w całość zupełnie niedopasowanych do siebie fantazmatów. W Etyce Spinoza próbuje zdać sprawę z faktu, który usiłowałam przybliżyć, odwołując się do procesu pływania. Rozpatrując jakiś stan rzeczy, mamy skłonność fiksować spojrzenie na jednym z obiektów i zapominać przy tym, że jego forma i forma przestrzeni, która go ściśle obejmuje, tworzą jedność, są tym samym i ściśle się determinują, tak jak ryba determinuje wodę, wypychając swym ciałem pewną jej objętość i jak woda odtwarza w sobie kształt ryby, ściśle przylegając do powierzchni jej ciała. Ulegając tej skłonności, dama potrącana plecakiem nie wyobrazi sobie, jak to jest dźwigać go w tłumie napierającym zewsząd i dodającym bagażowi ciężaru w chwili, gdy podczas gwałtownego hamowania pasażerowie ( $w$ tym ona sama) bezwładnie zatrzymują się na nim, gdyż siebie pojmuje jako siebie samą, a nie jako część masy pojazdu. Podobnie student: aby ocaleć w tłumie podczas długiej podróży, przywykł celowo ograniczać swą uwagę do muzyki i do sygnałów, wskazujących zbliżanie się docelowego przystanku. Zachowując się ${ }^{35} \mathrm{w}$ taki sposób, „odcinając się od tłumu”, nie wyobrazi sobie, co odczuwa pasażer mający do czynienia z jego plecakiem, kie-

${ }^{35}$ Zwrot „zachowywać się” zdumiewająco dobrze oddaje Spinozjańską ideę dążenia każdej rzeczy do pozostawania w stanie, który udało się jej osiągnąć. Podobnie fraza „ocaleć w tłu- 
dy autobus z uszkodzonym sprzęgłem szarpiąc rusza z miejsca. Wczuwanie się w cudze położenie, wyobrażanie sobie czyichś doznań to sięganie wstecz do śladów własnych, a nie cudzych postrzeżeń. Nawet gdy ktoś opowie mi o tym, co przeżył, zasłyszane słowa mogę powiązać wyłącznie ze śladami we własnym ciele i zrozumieć je tylko w kontekście własnego, a nie cudzego doświadczenia.

Wyobraźnia zawraca uwagę umysłu wstecz, pod prąd czasu, w którego głównym nurcie zdarzenia płyną nadal. Kiedy w pobliżu takiego wycofanego w głąb umysłu człowieka zdarzy się coś, co wytrąci go z wewnętrznej wędrówki w przeszłość, na przykład przeciąg zamknie z trzaskiem drzwi, a huk dotrze do jego świadomości wraz z poczuciem gwałtownego wzdrygnięcia się całego ciała, czuje się on tak, jakby się nagle obudził i przez mgnienie oka zdaje się nie wiedzieć, gdzie jest. Podobny efekt mógł się dokonać w świadomości młodego człowieka, do którego uszu poprzez muzykę sączącą się ze słuchawek wdarł się nagle wysoki głos, domagający się czegoś od niego. Zaskoczenie, którego doświadczył, musiało być niemałe; trzeba było ułamka sekundy, by mógł zrozumieć, czego się od niego żąda. Ten moment wystarczył, by udało mu się znaleźć sposób wykpienia się od odpowiedzi na zadane pytanie i zmyślenie sobie czegoś. „Że pani tu nie ma” - niestety, tego ludzka wyobraźnia nie jest w stanie stworzyć z dostępnych jej obrazów. Także i ona ma swoje ograniczenia.

Z powyższych fragmentów i uwag płynie wniosek, że zarówno arystotelesowskie, jak i stoickie ujęcie kwestii wyobraźni, odniesione do koncepcji Spinozy, może okazać się przesadnie optymistyczne. Według Arystotelesa rozum, jeśli nie jest przyćmiony namiętnością albo chorobą, potrafi okiełznać wyobrażenia, stoicy zaś zachęcają do czynienia z nich właściwego użytku, najwyraźniej pewni, że zadanie to jest wykonalne. W teorii Spinozy problem, jaki stwarza nam wyobraźnia, wydaje się nieusuwalny. Nie można bowiem ani dowolnie sterować wyobrażeniami, ani uczynić z nich żadnego w ogóle użytku, ponieważ sama ich wielość wprowadza umysł w kardynalny błąd, którego nie skoryguje on inaczej, jak tylko całkowicie usuwając je z pola rozważań. Pamiętajmy, że żądanie to dotyczy także słów, zwrotów mowy i jej wewnętrznej struktury, a zatem - że krok ten jest w oczywisty sposób niewykonalny. Pozostaje więc inny wybieg, tak radykalny, że nawet stoicy nie posunęli się do proponowania go filozofom. Umysł ludzki musi nauczyć się

mie" - wskazuje nie tylko na aspekt fizycznego zagrożenia, ale również na tendencję chronienia integralności psychicznej. 
działać pomimo wyobraźni, a kiedy jęzory jej fal wyrzucą na plażę rozumu (intelektu i ratio) brudną pianę mętnych i splątanych obrazów, odróżnić je jako takie od swoich jasnych i wyraźnych idei, po czym wrócić do rozważania całości i jedności natury.

Istnienia wyobrażeń zignorować nie sposób; można za to - niemałym wysiłkiem - próbować osłabić ich wpływ na działanie ratio i intelektu, dokonując uprzednio rewolucji w systemie pojęć (idei, a nie słów), użytych jako podstawy myślenia. Ślady spostrzeżeń odciśnięte w naszych ciałach przez rzeczy zewnętrzne w dalszym ciągu będą trwały, mieszały się z sobą i zacierały, tak jak działo się to dotychczas, ale osłabnie moc, z jaką przemawiają do rozumu (intellectus), gdy każde $\mathrm{z}$ nich zostanie sprowadzone do roli modyfikacji substancji albo natury.

Spinoza nie mówi tego jako teoretyk. Szarpania się w matni, w jaką imaginacja potrafi wciągnąć ludzki umysł, zaznał „na własnej skórze”. Wiadomo z jego biografii, że wyjazd z Amsterdamu po klątwie, zakazującej Żydom zbliżać się do niego, przyspieszył nocny atak szaleńca, który zaatakował go nożem. Obrazy tego zajścia, nawracające natrętnie i narzucające się umysłowi i ciału w postaci przyspieszonego, spłyconego oddechu, szybkiego tętna i uczuć strachu, gniewu, zaskoczenia ${ }^{36}$, a nawet ciekawości potraktował jako pierwszorzędny materiał do analizy biernych afektów. Innym udokumentowanym przykładem jest list do P. Ballinga, w którym Spinoza dzielił się $\mathrm{z}$ adresatem treścią swego snu i analizował pochodzenie natrętnych widziadeł, mącących mu potem spokój jeszcze wielokrotnie w ciągu dnia. Opisywał Ballingowi, jak uporczywie i żywo obrazy ze snu wyrastały mu pod powiekami, gdy tylko jego wzrok zaczynał błądzić w przestrzeni izby, jak odkrył, że zacierały się one pod napływem kolejnych wrażeń i doznań ${ }^{37}$. W obydwu tych, a z pewnością także i wielu innych przypadkach nie ulega wątpliwości, że Spinoza rozmyślnie używał własnych przeżyć, a nie wspomnień o nich. $\mathrm{W}$ chwili, gdy się rozgrywały, przeżywało je jego ciało, natomiast rozum abstrahował nawet od poczucia ucieleśnionego ,ja”, aby w ten sposób, oderwany, wolny i zdystansowany, móc jako widz oglądać ludzką "tragedię"38.

\footnotetext{
${ }^{36}$ Zbeletryzowaną analizę przeżyć i osobowości Spinozy przedstawił amerykański psychiatra i terapeuta nurtu egzystencjalnego, Irvin D. Yalom w książce Problem Spinozy, Warszawa 2012. ${ }^{37}$ Zob. list do P. Ballinga, w: B. Spinoza, Listy mężów uczonych do Benedykta de Spinozy oraz odpowiedzi autora wielce pomocne dla wyjaśnienia jego dzieł, tłum. L. Kołakowski, Warszawa 1961, list 17, s. 77.

${ }^{38}$ Por. rozdziały 21, 23 i 25 w: I. D. Yalom, Problem Spinozy.
} 
Wspomniane zdarzenia stały się częścią materiału niezbędnego do analizy przebiegu procesu postrzegania, roli wyobrażeń w poznaniu, a także możliwości rozumu (tak ratio, jak i intelektu) w odniesieniu do wyobrażeń, pamięci, mowy i sposobu uwalniania się od afektów. Obraz, czyli pobudzenie oka i dalej - całego ciała, a także idea tego pobudzenia w umyśle, nakłada się na inny, wcześniejszy ślad światła w ciele i stanowi tło dla następnych wrażeń. Wyobrażenia, czyli zatrzymane w umyśle idee, trwają w nim jako residua, bez których kolejne postrzeżenie rejestrowałoby się jako pierwsze, niezwiązane, pozbawione - jak to dziś powiadamy - kon-tekstu, czyli słów, ożywających w pamięci ciała, gdy powstaje w nim świeży ślad, podobny do już zapisanego postrzeżenia. Wewnętrzna mowa, samorzutnie komentująca wrażenia i nasze na nie reakcje, znana każdemu $\mathrm{z}$ nas, więc także i Spinozie, to właśnie wyobraźnia, która dawno już „przesądziła” o tym, jak się rzeczy miały i o tym, jak potoczą się następne zdarzenia. Dawne skojarzenia i ślady minionych spostrzeżeń, niby zapomniane, ale zapisane w historii naszego trwania, stale dobywają się z głębi pamięci i biegną do drzwi umysłu, ku zmysłom, by nowicjuszy, wrażenia rodzące się w nas aktualnie, powitać i zamknąć w swych objęciach.

Spinozjańska etyka nie dzieli wyobrażeń na obojętne, pożyteczne i szkodliwe. Wszystkie one są naturalnymi produktami procesu mentalnego, pospolitymi treściami umysłu. Nie jest zadaniem filozofii wyklinać, drwić i szydzić $\mathrm{z}$ tego, co istniejąc w naturze, działa na swój sposób. Wyobraźnia jak membrana, przepuszczalna granica pomiędzy umysłem i niektórymi innymi ideami natury, dołącza ich obrazy do jego treści. Do istoty umysłu należy także ratio zdolna ujmować wszelkie idee substancji i intellectus oglądający je jako idee Boga. Dopóki każda z tych władz z osobna czyni to, co do niej należy, a nie przygląda się działaniu pozostałych, człowiek postrzega, rozumuje i rozumie - rzeczy konieczne i niezmienne ma za podstawę możliwych i przemijających, nie miesza jednych $\mathrm{z}$ drugimi, nie pożąda niemożliwego ani nie obawia się koniecznego. Nie potrzebuje etyki innej, aniżeli ta, której podlegają wszelkie rzeczy natury.

Wiedząc, że rzecz bądź osoba, z którą lub o którą się zmagamy, w istocie nie jest odrębnym od nas bytem o nieznanej nam mocy i możliwościach, kimś lub czymś, co da się pokonać sprytem, podstępem, siłą albo umiejętnością, tylko tak jak my stanowi jeden z nieskończenie wielu sposobów przejawiania się natury, gdy pamiętamy, że nasze postrzeganie tej osoby lub rzeczy nie mówi ani o niej, ani o nas, ani nawet o naturze, tylko o sposobie układania się słów i obrazów w wyobraźni, stajemy jakby w pół drogi pomiędzy 
substancją i jej modyfikacjami, w dystansie (spatium) wobec ich skrajności, jak w oku cyklonu, gdzie trwa cisza. Z tego punktu można spokojnie patrzeć i rozważać, czym jest burza wyobrażeń, podziwiać moc i piękno tego przejawu natury w nas.

\section{Abstract \\ Understanding Imagination}

Keywords: imagination, fancy, perception, affection, Stoicism, Spinoza, Ethics, passive state, words, notions, reason, understanding

Imagination (imaginatio) plays a specific role in Spinoza's Ethics. Similarly to Epictetus' pavtaria it is the source of affections of body and mind. Proper understanding of the origins of acataleptic perceptions (Epictetus) and imaginations (Spinoza) together with their interactions enable mind to get free from passive states and to reach happiness. In Ethics imagination can be found wherever images are formed - in eyes, that is in body, whereas in mind an occurrence parallel to affection of optic nerves is a perception, or comprehending an idea. In the article I try to present this "parallelism" of psychophysical occurrences by referring to everyday examples. 